\title{
Impacts of Benzyl Butyl Phthalate on Histo-Architecture of Gonads of African Catfish Clarias gariepinus (Burchell, 1822)
}

\author{
Lankesh Yashwant Bhaisare ${ }^{1}$, Suresh Bapurao Zade ${ }^{2}$, \\ Aashikkumar Madhukar Nagwanshi², Aashish Kumar Netam', \\ Desh Deepak Chaudhary ${ }^{1 *}$
}

${ }^{1}$ Department of Zoology, Indira Gandhi National Tribal University, Amarkantak, Madhya Pradesh 484887, India

${ }^{2}$ Department of Zoology, Rashtrasant Tukdoji Maharaj Nagpur University, Nagpur, Maharashtra 440033, India

Received: 28 May 2021

Accepted: 10 September 2021

\begin{abstract}
The presence of endocrine-disrupting chemicals (EDCs) in various environments indicates a serious problem due to their persistent nature and their varied toxic effects to the different organisms. Phthalates are a class of EDCs that include industrial chemicals with a wide range of toxicological properties. Due to varied use of phthalates and its leaching property, it ultimately concentrates into the water bodies for high health risk. So, the present study was designed to elucidate the effect of Benzyl Butyl Phthalate (BBP) on the gonads of African catfish, Clarias gariepinus. The fishes were exposed to the BBP at low $(2 \mathrm{mg} / \mathrm{L})$ and high $(6 \mathrm{mg} / \mathrm{L})$ doses for 5 and 10 days for both the concentration. Significant exposuredependent alterations were observed in the histological structure of gonads of both male and female. The ovaries showed severe disruption of the ovarian follicles, disintegrated nucleus, nucleolar vacuolization, disorganize nucleolar ring, fused and disintegrated oocytes. In the case of testes, it showed vacuolization in the seminiferous tubules, empty and disintegrated seminiferous tubules, degeneration of germ cells, and hypertrophy of Sertoli cells. Thus, such histological changes of the gonads due to BBP may impair the normal reproductive function in both male and female C. gariepinus.
\end{abstract}

Keywords: EDCs, phthalates, histopathology, ovary, testis

\section{Introduction}

Environmental compounds belong to the endocrinedisrupting chemicals (EDCs) are a diverse group of the worldwide synthetic or natural substances defined

*e-mail: ddchaudhary90@gmail.com according to its endocrine activity, adversity of effects, and a possible correlation cause-effects [1]. EDCs can be used in industry for the different applications such as lubricants and solvents (polychlorinated biphenyls, polybrominated diphenyl ethers and dioxins) [2-4], plastics (bisphenol $\mathrm{A}$ and S) [5, 6], pesticides and herbicides (atrazine, cypermethrin, dichlorodiphenyltrichloroethane, dieldrin, methoxychlor, and vinclozolin) [4, 7], and organic compounds 
(diethylstilbestrol, ethyl estradiol) [8], plasticisers (phthalates) [4].

It has been shown that the primary source of EDCs exposure to humans and animals are the ingestion of contaminated food and water [9, 10]. However, it can also occur through the inhalation of the contaminated air and through the skin contact [11]. Moreover, recently it has been also observed that human can expose through the medical consumables and devices such as catheters, breathing and respiratory equipments, and blood bags which contain different mixtures of EDCs [12]. EDCs can affect multiple endocrine pathways, particularly it shows serious impact on the different reproductive pathways. Among all of them, disturbance of estrogen or androgen-mediated processes [13, 14] are the most common pathway. Most of the EDCs are xenoestrogens, which are able to bind with the estrogen receptor [15]. Thus, EDCs can affect the different biological systems through agonistic or antagonistic interactions with receptors and alters the hormone levels in the body [16-18].

Phthalates are industrial chemicals with different applications and toxicological properties. Specifically, they are used as plasticizers to add softness, flexibility, durability, transparency, and longevity to a variety of consumer, industrial, and medical products [19, 20]. They are broadly used in the manufacture of plastics, solvents, sealants, paints, varnishes, detergents, and some personal care products, toys, household products, as well as in the food processing, and pharmaceutical industries $[19,21]$. They are classified into two distinct groups based on their molecular weight: (a) high molecular weight compounds (di-2-ethylexyl phthalate), primarily used as plasticizers in the manufacture of flexible vinyl plastic present in consumer products, flooring and wall covering, and medical devices [11]; (b) low molecular weight compounds (diethyl phthalate and dibutyl phthalate), used in personal care products such as solvents for perfumes and fixatives for the hair spray [22], as solvents and plasticizers for cellulose acetate [11].

Moreover, much importance has been given to phthalate metabolites such as three di-(2-ethylexyl) phthalates, mono-(2- ethylexyl) phthalate (MEHP), mono-(2-ethyl-5-hydroxyhexyl) phthalate (MEHHP), and mono-(2-ethyl-5-oxohexyl) phthalate (MEOHP) [11]. Among these phthalates, di-2-ethylexyl phthalate and dibutyl phthalate are the most widely used for flexibility and transparency to numerous plastics made of polyvinyl chloride (PVC) [23]. Since phthalates are not covalently bound to the polymer, they can leach from the plastics into foods, water, beverages, and body fluids [12, 24]; with product age, use, and ultraviolet light exposure, making them available for biological exposure [19].

With wide variety of physical and chemical properties, phthalates are used in a multitude of consumer and industrial products that demands high performance, long lasting and durability. While they can be employed in a variety of applications, phthalates are not necessarily interchangeable. The characteristics of individual phthalates often make it well suited to a particular products, allowing manufacturer to meets unique requirements for its use (function and safety specification), appearance (texture, color, size and shape) and durability. For this reason, substitutions could sacrifice the functionality, quality, longevity, cost or performance of the product. With the varied range of uses of phthalates they tends to come frequently in contact with human and other organisms.

Therefore, the present study had been conducted to study the effect of exposure to benzyl butyl phthalate, a member of the phthalate family on the histological architecture of gonads of African catfish Clarias gariepinus. The air breathing freshwater African catfish, Clarias gariepinus was selected for the present study as they are available throughout the year and can be easily transported and maintained in laboratory conditions. Moreover, the fish is known for its high tolerance capability and survivability. It also have high resilience power in harsh habitat conditions. It has a high tolerance capability and a hardy nature, making it ideal for experimentation.

\section{Materials and Methods}

\section{Collection and Maintenance}

Clarias gariepinus, also known as African mud catfish, exists in the wild but it is also cultivated in ponds, and cages for different commercial importance. This is an omnivorous fish with a preference of planktonic diet [25]. It also feeds on the other types of food items such as insects, insect larvae and pupae, fish and fish remains. So, it also has a propensity for being carnivorous. All the fishes, which have been used in the present study, were brought from the local market of Nagpur, Maharashtra $\left(21^{\circ} 8^{\prime} 47.8788^{\prime \prime} \mathrm{N}\right.$ and 79'5'19.8960' $\mathrm{E})$. The body weight of fishes were $300 \pm 25 \mathrm{gm}$ and their length were $33.50 \pm 05 \mathrm{~cm}$. The fishes were maintained in a glass aquarium containing 30 litres tap water, with normal abiotic conditions. Before the experiment, the fishes were acclimatized for one week by keeping 6 fishes in one aquarium. The fishes were fed with minced goat liver every alternate day and water was changed at the interval of one day.

\section{Experimental Design}

For the present study, the chemical Benzyl butyl phthalate (No.: RM7882) was purchased from HiMedia laboratories Pvt. Ltd. (CAS No.: 85-68-7). The three aquariums were taken filled with 30 litres of tap water and each aquarium was occupied with 3 male and 3 female fishes. In those three aquariums, fishes were grouped as control treatment, low dose treatment $(2 \mathrm{mg} / \mathrm{L})$ and high dose treatment $(6 \mathrm{mg} / \mathrm{L})$ respectively, 
and labelled them accordingly. The experimental fishes were treated by adding benzyl butyl phthalate in the aquarium for 5 and 10 days. After 5 and 10 days, the fishes of all three treatments were sacrificed for histological examination of gonads (testis and ovary). Small pieces of the gonads were taken and immediately fixed in Bouin's fixative. Fixed tissues were processed routinely for the paraffin embedding technique. Embedded tissues were sectioned at $5 \mu$ in thickness and then stained with Eharlich Hematoxylin and eosin stain $(\mathrm{H} \& \mathrm{E})$ and mounted in DPX. The slides were observed under the microscope at 100X and 400X.

\section{Observations and Results}

In the slides, lesions were observed in gonads of treated fishes for both the experimental treatments in compared to the control treatment. The occurrence and degree of alteration in gonads were positively related to the doses of the BBP. The following changes were observed in the ovary and testis.

\section{Histopathological Changes in the Ovary}

The ovary of the fishes of control group were showed four stages of the follicular development which were chromatin nucleolus stage, early perinucleolus stage, late perinucleolus stage, and primary yolk stage (Photoplate I)

Ovaries which were exposed with the $2 \mathrm{mg} / \mathrm{L}$ BBP for 5 days, showed the vaccuolation in the early perinucleolus stage follicles, atretic follicles, development of inter-follicular space in oocytes, degeneration of immature follicles, fusion of follicles, nuclear shrinkage, destructed of the follicular layer, disorganization of nucleolar ring, disintegration of the nucleus, and vacuolization in follicular layer (Photoplate II).
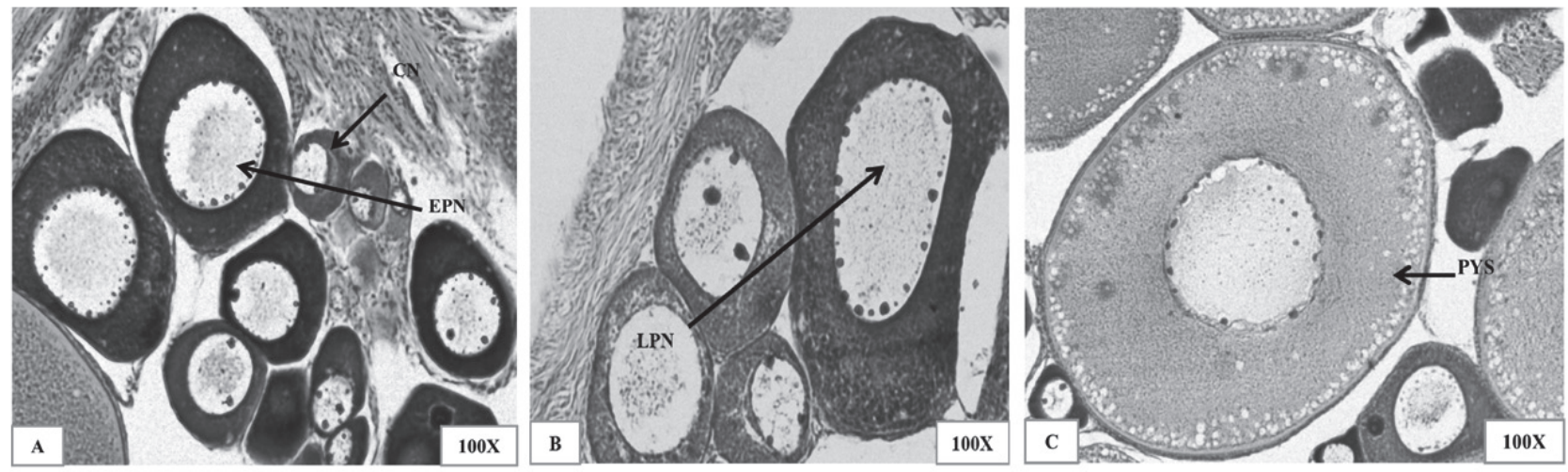

Photoplate I. Microphotograph showing histological structure in the ovary of control group of fish Clarias gariepinus showing (A) CN- Chromatin nucleolus stage, EPN- early perinucleolus stage (B) LPN- Late perinucleolus stage (C) PYS- Primary yolk stage.
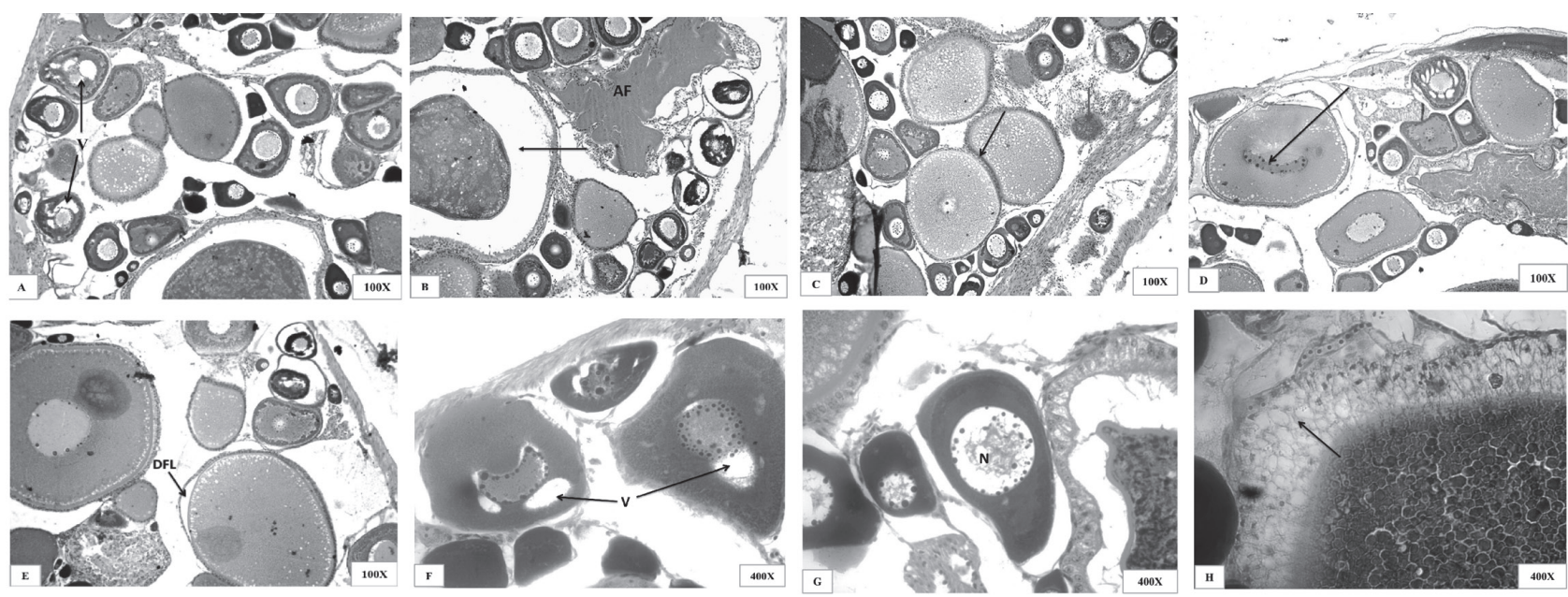

Photoplate II. Microphotograph showing histopathological changes in the ovary of fish Clarias gariepinus exposed to $2 \mathrm{mg}$ BBP for 5 days showing (A) V- Vacuolization in early perinucleolus (B) AF- Atritic follicle and development of intra-follicular space (C) Red arrow showing degeneration of immature follicle and black arrow showing fusion of follicles. (D) Nuclear shrinkage (E) DFLDestructed follicular layer $(F)$ V- Vacuolation in follicles $(G)$ N- Disorganization of nucleolar ring along with disintegration of nucleus.

(H) Vacuolization in the follicular layer. 
On the other hand, ovaries which were exposed to the $6 \mathrm{mg} / \mathrm{L}$ BBP for 5 days, showed change in the normal shape of the primary follicles, atretic follicles, degeneration of early yolk follicles, ruptured follicle layer, disintegration of the nucleus, severe vacuolization in the follicular layer, severe rupture in the follicular wall, fusion of follicles, and vacuolization in early perinucleolar stage of the follicles (Photoplate III).

For 10 days treatments, ovaries showed shapeless primary yolk follicles, atretic follicles, karyoplasmic clumping, degenerated nucleoli, severe vacuolization of late perinucleolus stage, disorganization of nucleolar ring, nucleolar vacuolization, and fusion along with disintegration of oocytes (Photoplate IV) when exposed to $2 \mathrm{mg} / \mathrm{L}$ BBP.

On the other hand, ovaries were exposed to the $6 \mathrm{mg} / \mathrm{L}$ BBP for 10 days, showed cytoplasmic liquefaction, degeneration of the nuclear membrane, karyoplasmic clumping, shapeless perinucleolar stage follicles, disintegration of follicles, destructed follicular layer, fusion of follicles, nuclear vacuolization, and shapeless follicles (Photoplate V).

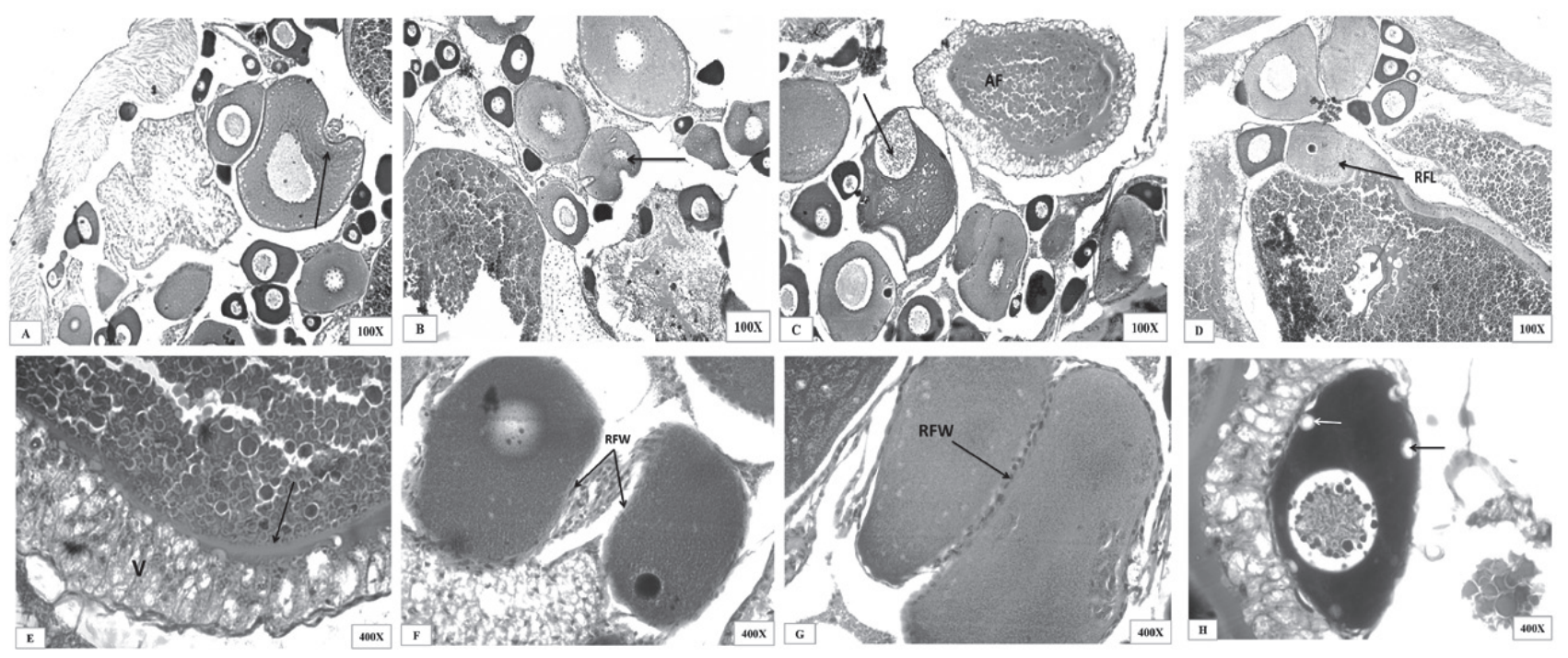

Photoplate III. Microphotograph showing histopathological changes in the ovary of fish Clarias gariepinus exposed to 6 mg BBP for 5 days showing (A) and (B) changes in the normal shape of primary follicle (C) AF- atretic follicle and black arrow showing degeneration of early yolk follicle (D) black arrow showing RFL- ruptured follicle layer and red arrow showing disintegration of nucleus (E) severe V- vacuolization in follicle layer (F) severe RFW- rupture of follicular wall (G) rupture of follicular wall along with fusion of follicles $(\mathrm{H})$ vacuolization in the early perinucleolus stage of follicles.
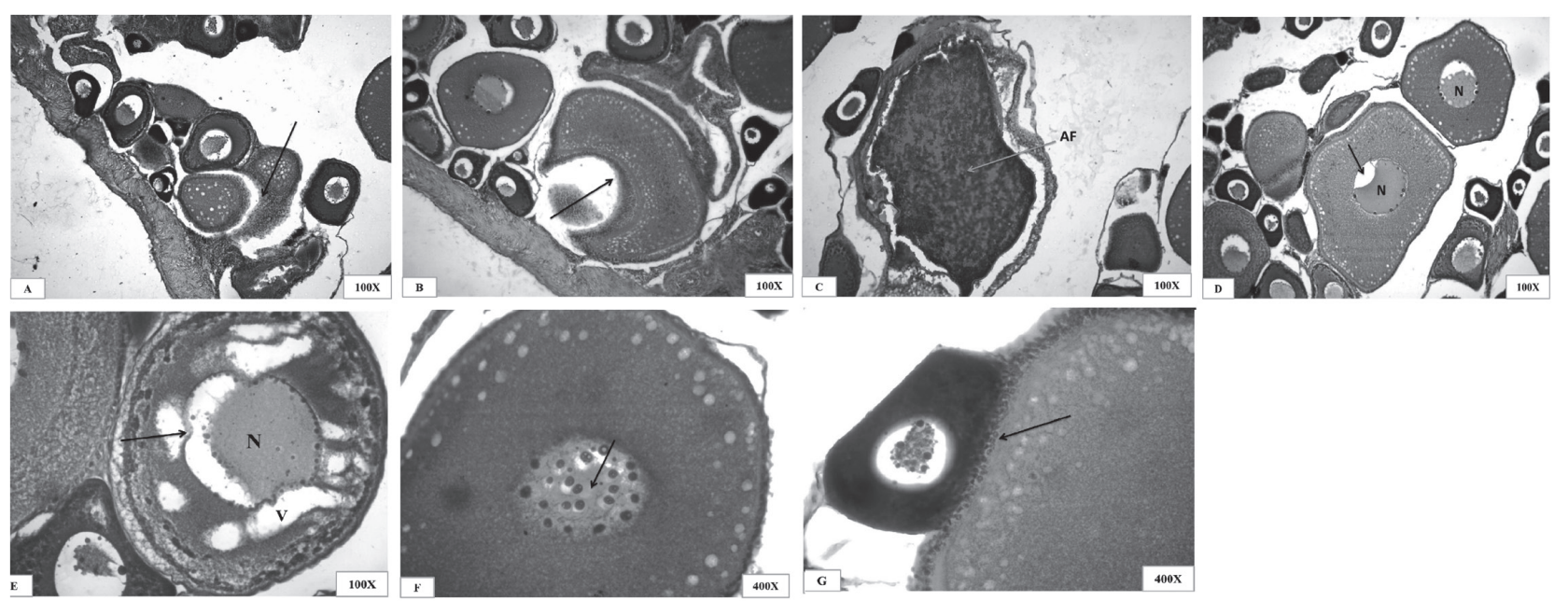

Photoplate IV. Microphotograph showing histopathological changes in the ovary of fish Clarias gariepinus exposed to $2 \mathrm{mg}$ BBP for 10 days showing (A) and (B) shapeless primary yolk follicle (C) AF- atretic follicle (D) karyoplasmic clumping along with degenerated nucleoli (E) severe vacuolization in late primary follicle stage (F) disorganization of nucleolar ring along with nucleolar vacuolization (G) fusion and disintegration of oocyte. 


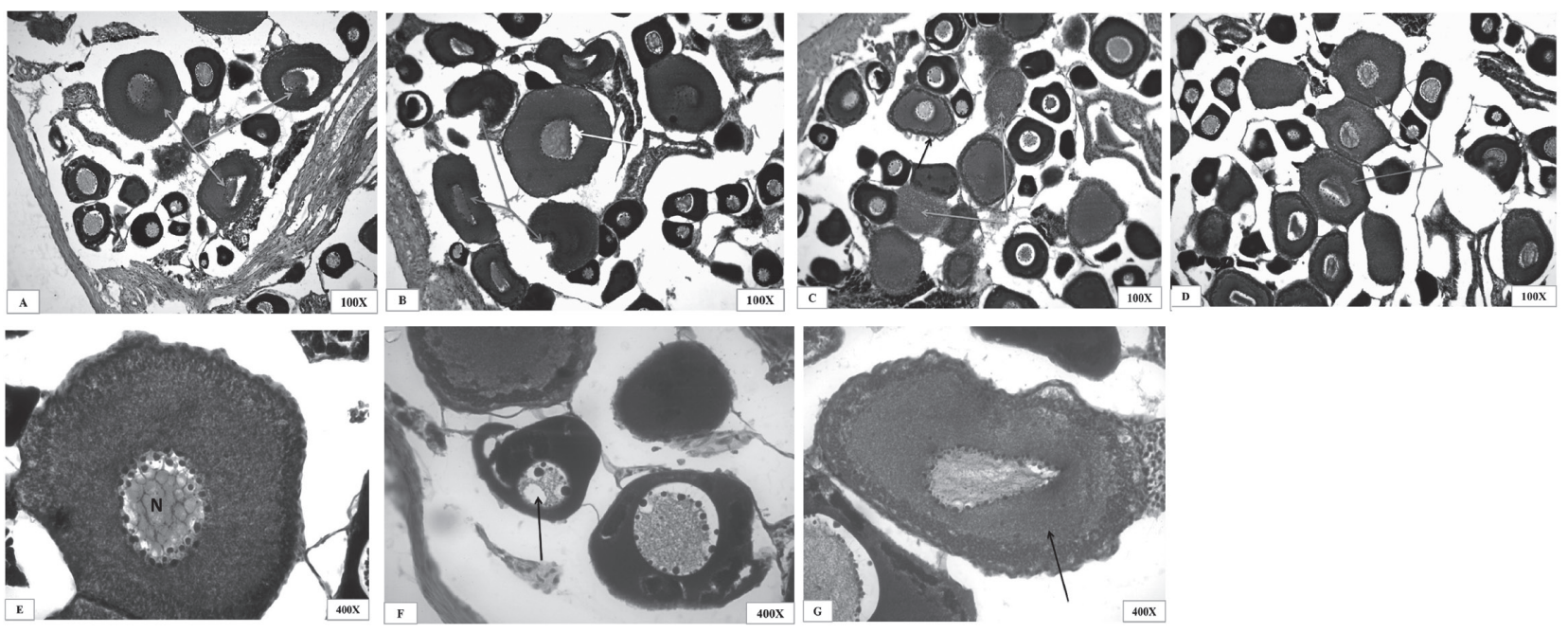

Photoplate V. Microphotograph showing histopathological changes in the ovary of fish Clarias gariepinus exposed to $6 \mathrm{mg}$ BBP for 10 days showing (A) cytoplasmic liquefaction along with degeneration of nuclear membrane (B) white arrow showing karyoplasmic clumping and red arrow showing shapeless late perinuclear stage follicle (C) yellow arrow showing disintegration of follicles and black arrow showing disintegrated follicular layer (D) fusion of follicles (E) and (F) nuclear vacuolization (G) shapeless follicle.

Histopathological Changes in the Testis

The testes of the control group was showed various developmental stages such as primary spermatogonia, secondary spermatogonia, primary spermatocytes, secondary spermatocytes, spermatids, and spermatozoa (Photoplate VI).

Histological examination of the testes of the fishes which were exposed to the $2 \mathrm{mg} / \mathrm{L}$ BBP for 5 days showed disorganization of seminiferous tubules, vacuolization in the seminiferous tubules, empty seminiferous tubules, degeneration of germ cells, hypertrophy of Sertoli cells, and disintegration of the cyst (Photoplate VII).
On the other hand, histological examination of the testes which were exposed to the $6 \mathrm{mg} / \mathrm{L} \mathrm{BBP}$ for 5 days showed vacuolization in spermatocyte, disintegration cyst of spermatocytes, uneven distribution of spermatozoa, degenerated spermatozoa, degeneration of seminiferous tubules, hypertrophy of Sertoli cells, and clumping of spermatozoa (Photoplate VIII).

In the 10 days treatments, in which testes of the fishes were exposed to $2 \mathrm{mg} / \mathrm{L}$ BBP, showed degeneration of seminiferous tubules, empty seminiferous tubules, vacuolization in spermatogonia cells, and hypertrophy of Sertoli cells (Photoplate IX).

For the same duration as above when testes of fishes were exposed to the $6 \mathrm{mg} / \mathrm{L}$ BBP, showed degenerated
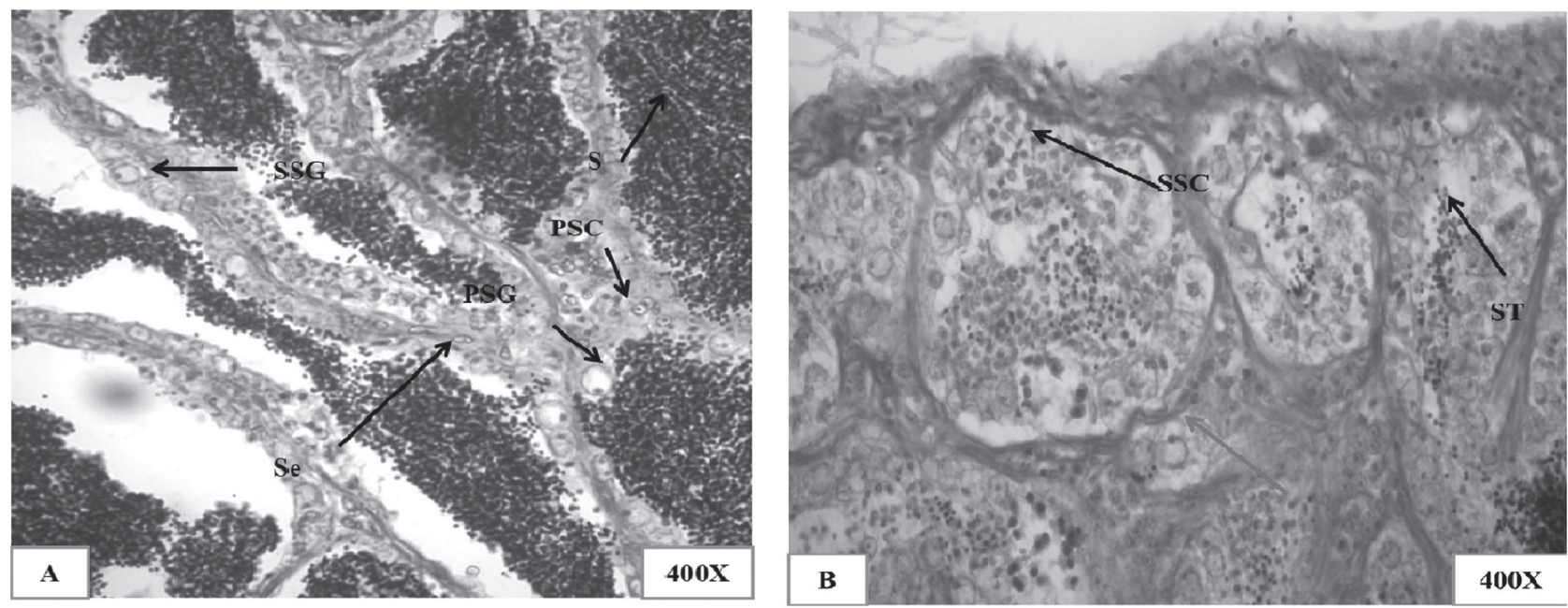

Photoplate VI. Microphotograph showing histological structure in the testis of control group of fish Clarias gariepinus showing (A) SSG- secondary spermatogonia, S- spermatozoa, PSG- primary spermatogonia, Se- sertoli cell, PSC- primary spermatocytes (B) SSCsecondary spermatocytes, ST- spermatids, red arrow showing the seminiferous tubules. 

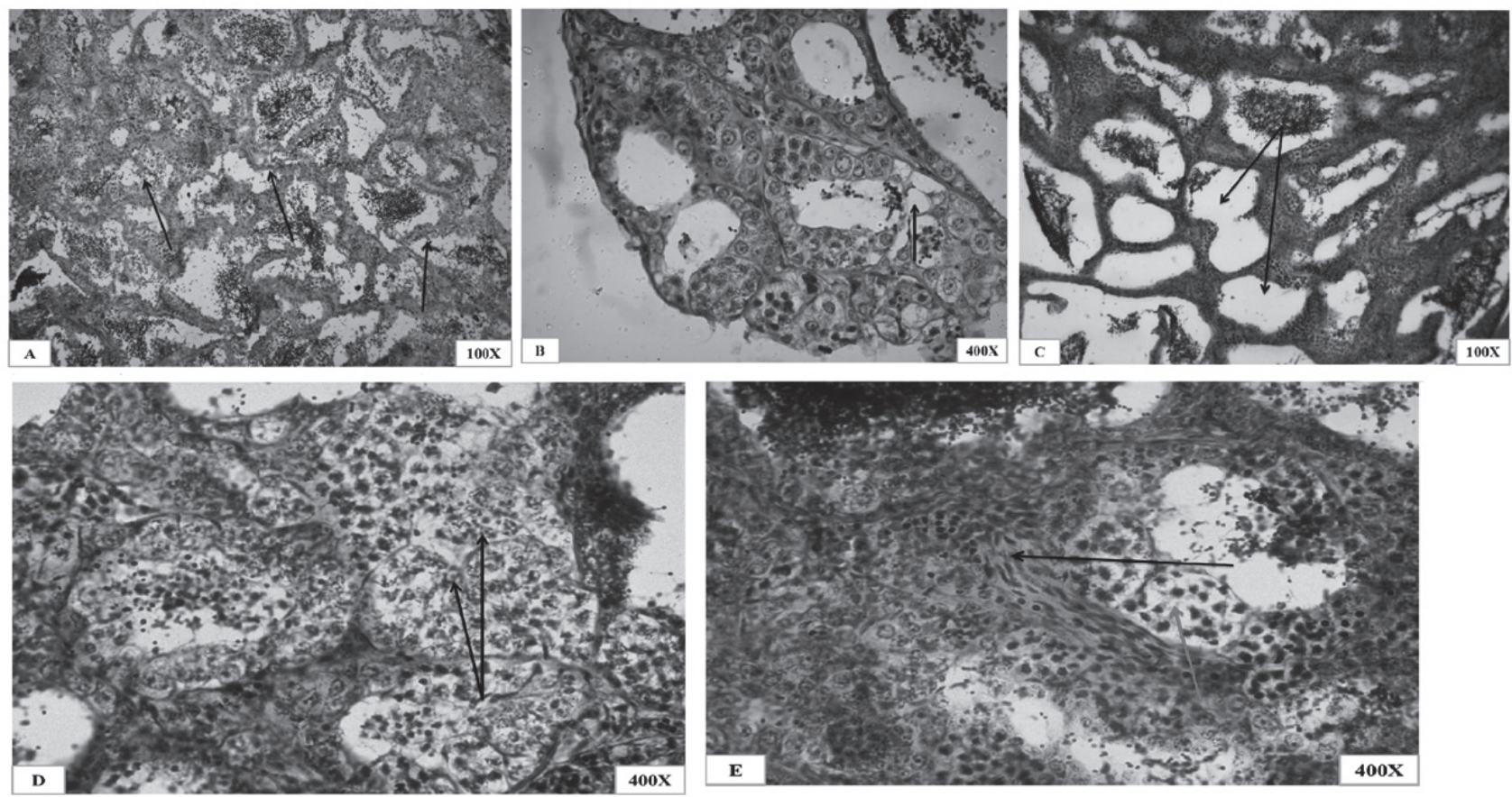

Photoplate VII. Microphotograph showing histopathological changes in the testis of fish Clarias gariepinus exposed to 2 mg BBP for 5 days showing (A) disorganization of seminiferous tubules (B) vacuolization in the seminiferous tubules (C) empty seminiferous tubules (D) degeneration of germ cells (E) black arrow showing hypertrophy of sertoli cell and red arrow showing disintegrating cysts.
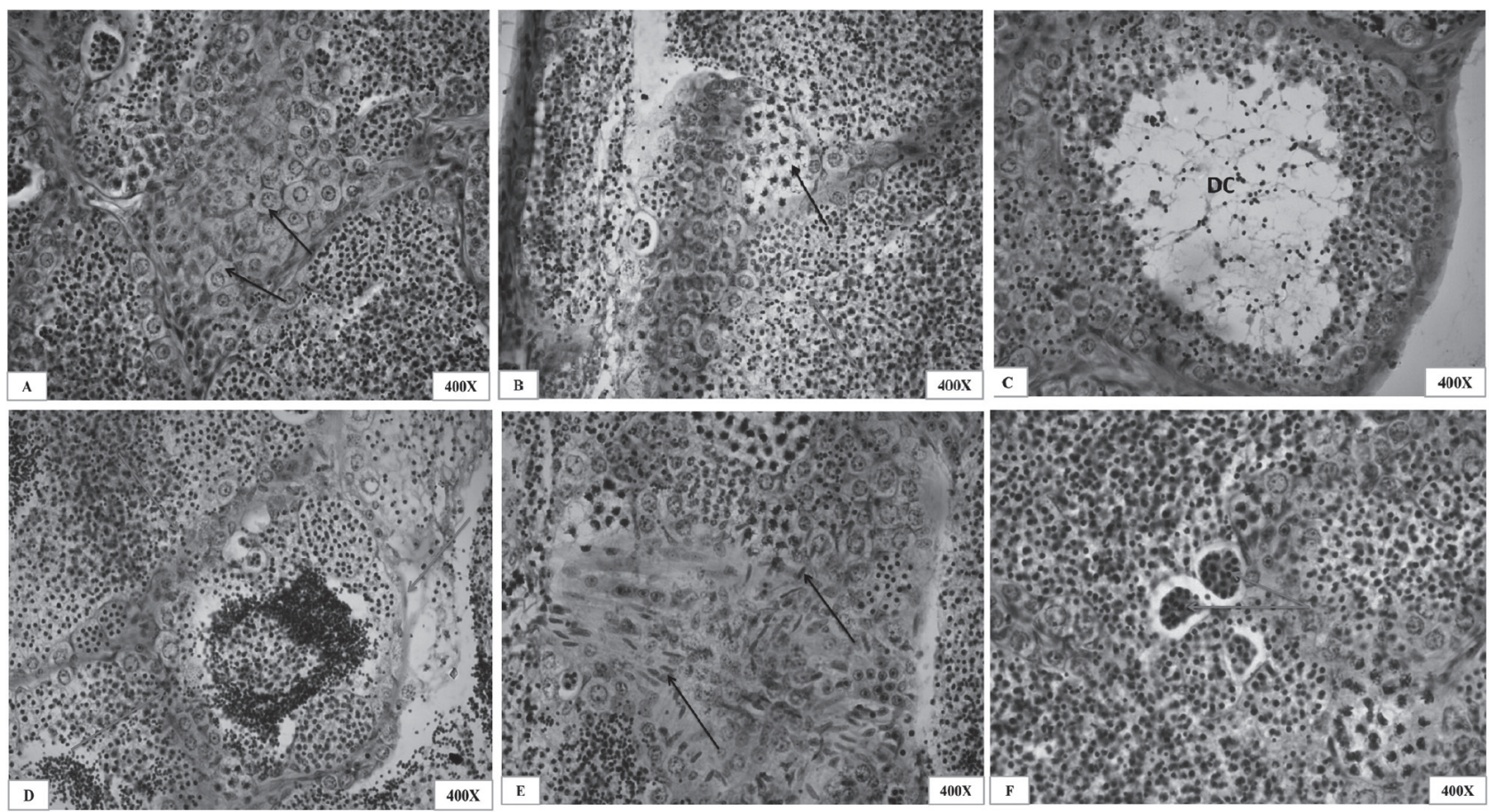

Photoplate VIII. Microphotograph showing histopathological changes in the testis of fish Clarias gariepinus exposed to 6 mg BBP for 5 days showing (A) vacuolization in spermatocyte (B) black arrow showing disintegrated cyst of spermatocytes and red arrow showing uneven distribution of spermatozoa (C) degenerated spermatozoa (D) degeneration of seminiferous tubules (E) hypertrophy of sertoli cells (F) clumping of spermatocytes. 
spermatozoa, the disintegration of seminiferous tubules, hypertrophy of Sertoli cells, and vacuolization (Photoplate X).

\section{Discussion}

\section{Histopathological Structure of the Ovary}

Gonadal histopathology particularly falls into the category of indicator that provides structural rather than functional information about gonadal health in response to the surrounding environments [26]. Gonadal development and its maturation go through the sequential changes which are associated with the different physiological processes.

In the present study, histological examination of the fish ovaries, showed degenerative effects when exposed to the different concentrations of BBP for short and long period such as vacuolation in the early perinucleolus stage follicles, atretic follicles, development of interfollicular space in oocytes, degeneration of immature follicles, the fusion of follicles, nuclear shrinkage, destructed follicular layer, disorganization of the nucleolar ring, the disintegration of the nucleus, vacuolization in the follicular layer, etc. (Photoplate II, III, IV and V). Almost similar observations were also witnessed by Yön \& Akbulut [27] in zebrafish when exposed with the Bisphenol A (BPA). The development of inter-follicular space in the ovary probably formed due to the shrinkage of oocytes. Similar observations were also recorded by EI-Ghamdi et al., [26] in Tilapia fish (Saratherodon galilaeus), when subjected to the disturbed urban stream [28].

Follicular atresia is a normal degenerative process in response to the chemicals in fishes and other vertebrate's ovaries, as it is also responsible for the pathological alteration in ovarian morphology [28, 29]. Zhang et al., [14] also reported that, the higher proportion of pre-mature oocytes and the occurrence of several atretic follicles in Gobious rarus when exposed to bisphenol A (BPA). The ovarian follicles lose their integrity, degenerate, and are subsequently eliminated before ovulation in the process of atresia. Moreover, an increase in the number of deformed follicles along with the presence of degenerating vitellogenic oocytes have been observed, suggesting a defect in follicle recruitment, when exposed with 2,4- Dichloro-6nitrophenol, a chloride-based herbicide to the Gobious rarus [30]. Similar findings were also observed in the present study.

Ferin, [31] reported that gonadal maturation in fishes is controlled by different hormones that are secreted through the hypothalamic-pituitary-gonadal (HPG)
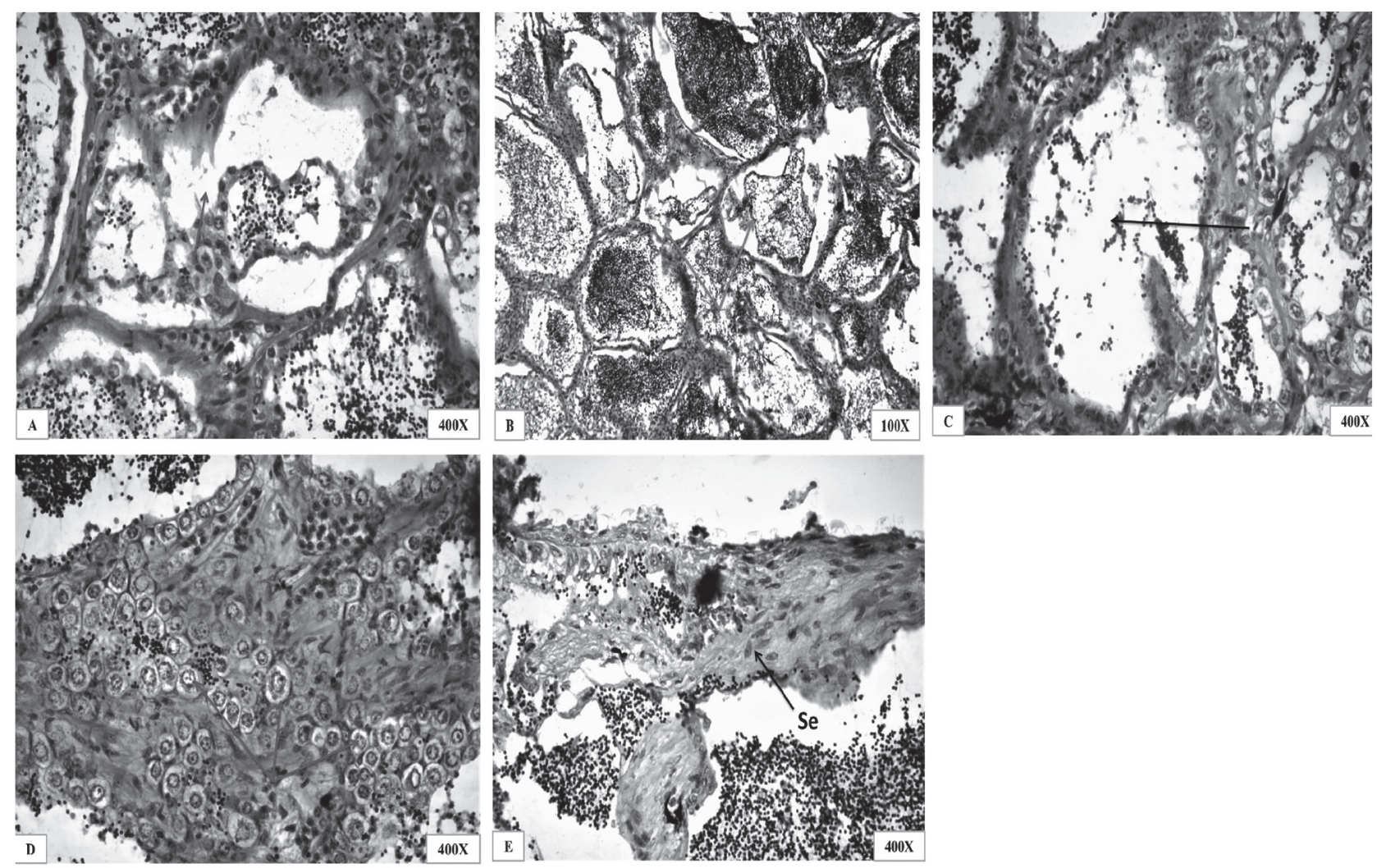

Photoplate IX. Microphotograph showing histopathological changes in the testis of fish Clarias gariepinus exposed to $2 \mathrm{mg}$ BBP for 10 days showing (A) and (B) degeneration of seminiferous tubules (C) empty seminiferous tubules (D) vacuolization in spermatogonial cell (E) hypertrophy of sertoli cell. 
axis. Atresia has often been reported as the reproductive toxicant effect, which is caused by endocrine-disrupting compounds [32, 33]. According to the Mir et al., [34], the inhibition of oogenesis, necrosis, fibrosis of lamellar walls, total disintegration of the different elements in many ovarian activities were formed by the folding of the ovigerous lamella. Almost, similar histopathological findings as observed in the present study has been reported by Peranandam et al., [35] in the ovaries of the Female Fresh Water Prawn Macrobrachium rosenbergii by the exposure of 10,100 , and $1000 \mathrm{ng} / \mathrm{L}$ of TBT concentration for 6 months. Apart from this, Rai et al., [36] reported the effects of Mercuric Chloride induced histo-anatomical alterations in the ovarian tissue of catfish, Channa punctata (Bloch) with similar findings.

Histological changes in ovaries may be caused by several factors, such as xenobiotic toxicants [37] and by a variety of effluents and aquatic pollutants [38]. After exposure, follicles exhibit degenerative changes, liquefaction of perinucleolus cytoplam and condensation of the nucleus, the disappearance of the nuclear membrane, cytoplasmic clumping, degenerated granulose layer, and degenerated ovarian wall and wrinkled oocytes. But a high dose of EDCs causes more pronounced histopathological lesions in oogonial cells, primary oocytes, and vitellogenic oocytes in female fish [39]. Many EDCs can interact with the female reproductive system and leads to endocrine disruption in the ovary by binding of the transcription factor to the receptors, EDCs can alter endocrine function through a variety of mechanisms like, it may alter the expression and/or activity of enzymes required for synthesis and/or catabolism of ovarian sex steroids. In some other cases, it may alter the expression of hormone receptors and/ or their ability to bind with their endogenous ligands. EDCs are chemicals that disrupt the endocrine system by activating or inhibiting receptors of the endocrine system, and/or altering hormone receptor expression, signal transduction, epigenetic marks, hormone synthesis, transport, distribution, and metabolism, and the fate of hormone-producing cells [40]. Many studies have shown a direct relationship between the body burden of chemicals in gravid females and the concentrations of these chemicals in the eggs [41]. Earlier research also has been reported that changes in gonadal structure are dependent on the potency of chemicals and its concentration in surroundings [38].

\section{Histopathological Structure of the Testis}

Seminiferous tubules are the basic unit for spermatogenesis and have primary importance in the testis because they hold and release the sperm for egg
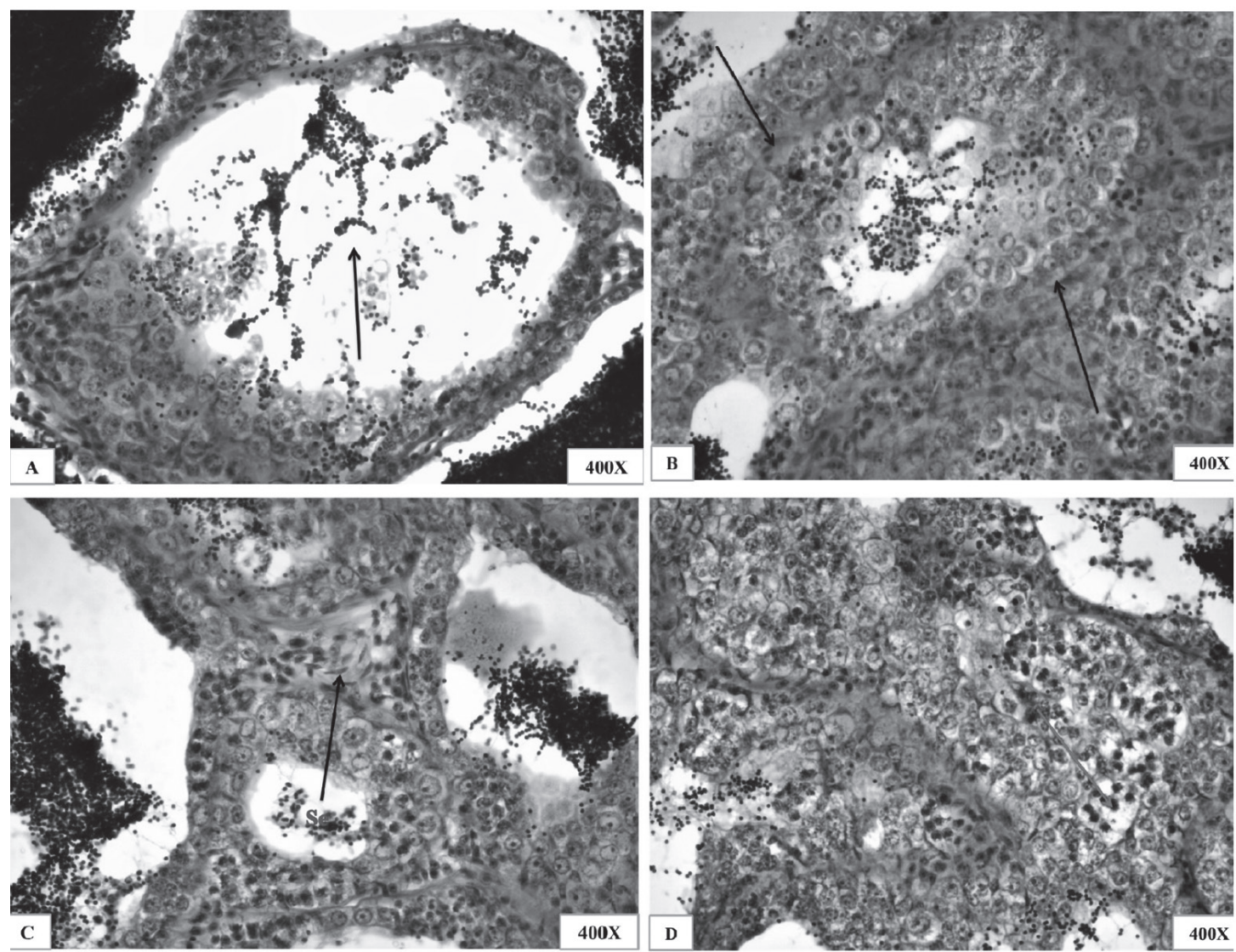

Photoplate X. Microphotograph showing histopathological changes in the testis of fish Clarias gariepinus exposed to $6 \mathrm{mg}$ BBP for 10 days showing (A) degenerated spermatozoa (B) disintegration of seminiferous tubules (C) Se- hypertrophy of sertoli cells (D) vacuolization 
fertilization [42]. Androgens hormones produced by the Leydig cells exerting a complex actions in the testis by targeting spermatogenic as well as Sertoli cells [43]. When experimentally, fishes were exposed to the low and high doses of the BBP at different exposure periods showed a considerable degree of alteration in histology of this unit such as disorganization of seminiferous tubules, vacuolization in the seminiferous tubules, empty seminiferous tubules, degeneration of germ cells, and disintegration of cyst, and clumping of spermatozoa, etc. (Photoplate VII, VIII, IX, X). These changes might be caused because the gonadal development ceases and steroidogenesis was markedly inhibited after the exposure to such endocrinedisrupting chemicals [44].

These effects were also reported by Lora Benitez et al., [45] in the testis of zebra fish (Danio rerio) when exposed to the different concentrations of BPA. Masouleh et al., [46] was also observed the effect of Diazinon on the testes of Rutilus frissi Kutum and observed the adverse effects on testis with decreased number of spermatozoa, sperms motility and concentration of sperm. Moreover, extensive damage to testicular architecture like thinning of the testicular walls, an increase in the interlobular areas, and loosely arranged cysts in combination with the marked disintegration were seen as toxic effect of endosulfan in the testis of the freshwater fish, Cyprinion watsoni [47].

Such histological changes observed in the testes of the fishes might be caused due to the disruption of the blood-testis barrier with a consequent chemical accumulation in tissue [48]. Changes in the permeability of the blood-testis barrier and alterations in testicular structure like germ cell loss, necrosis were observed in rats as a toxic effect of Bisphenol A [49]. Furthermore, Hayati et al., [50] observed the toxic effects of endocrine-disrupting metal Cadmium in fish and rats. Cadmium causing the several structural changes in testis, epididymis like cellular degeneration, necrosis that impaired Hypothalamic - pituitary-Gonad-Liver function (HPGL) axis function, leading to eventually hampering spermatogenesis process. In addition to the exposure of di-(2-ethylhcxyl) -phthalate (DEHP) a class of phthalate caused an increased oxidative stress in the Sertoli cells of the testis impairing the spermatogenesis [51].

Disrupted seminiferous tubules, degeneration of germ cells, and atrophy of Sertoli cells cause the abnormal development of testis. BBP causes a hazardous effect on the gonads which may be related to its effects on the HPG axis of fish which plays an important role in the reproduction of fish. It has been shown that phthalates affect the male reproductive system by acting as an anti-androgenic endocrine-disrupting compound that alters the steroidogenic capacity of steroid secreting cells of testis [21]. As a result, there is an interruption in the testosterone synthesis which in turn disrupts the differentiation of androgen-dependent tissues.
Thus, lowered testosterone concentrations could have associated with the adverse changes in the histological structure of testis which was observed in the present study.

\section{Conclusion}

The present work showed the varied toxic effects of Benzyl Butyl Phthalate on the histology of male and female gonads of $C$. gariepinus. Our histological reports showed that $\mathrm{BBP}$ can potentially disrupt the reproductive physiology of the fishes by causing several regressive changes in the gonads. In this context, the study highlights the need to perform long-term, systematic studies of lower concentrations of phthalates in natural water bodies. It is also important to track the effects of other phthalates on fish reproduction. Further studies need to be conducted on the impact of phthalate mixtures since these are what mainly occur in the natural environment.

\section{Author's Contribution}

Suresh Bapurao Zade contributed to conception and design of the study. Lankesh Yashwat Bhaisare and Aashikkumar Madhukar Nagwanshi had performed the experiments, drafted the manuscript. Aashish Kumar Netam helped in drafting and editing of the manuscript. Desh Deepak Chaudhary contributed to conception, select items in the drafted manuscript, critically revised manuscript and gave final approval to the manuscript.

\section{Conflict of Interest}

It is certified that all authors have contributed significantly, and all authors are in agreement with the content of the manuscript and have no conflicts of interest.

\section{References}

1. SVECHNIKOV K., STUKENBORG J.-B., SAVCHUCK I., SODER O. Similar causes of various reproductive disorders in early life. Asian Journal of Andrology, 16 (1), 50, 2014.

2. POCAR P., FIANDANESE N., SECCHI C., BERRINI A., FISCHER B., SCHMIDT J.-S., SCHAEDLICH K., RHIND S.M., ZHANG Z., BORROMEO V. Effects of Polychlorinated Biphenyls in CD-1 Mice: Reproductive Toxicity and Intergenerational Transmission. Toxicological Sciences, 126 (1), 213, 2012.

3. DE FALCO M., FORTE M., LAFORGIA V. Estrogenic and anti-androgenic endocrine disrupting chemicals and their impact on the male reproductive system. Frontiers in Environmental Science, 3, 2015.

4. ENCARNACAO T., PAIS A.A., CAMPOS M.G., BURROWS H.D. Endocrine disrupting chemicals: Impact 
on human health, wildlife and the environment. Science Progress, 102 (1), 3, 2019.

5. RUBIN B.S. Bisphenol A: an endocrine disruptor with widespread exposure and multiple effects. The Journal of Steroid Biochemistry and Molecular Biology, 127 (1-2), 27, 2011.

6. VINAS R., WATSON C. S. Bisphenol S Disrupts EstradiolInduced Nongenomic Signaling in a Rat Pituitary Cell Line: Effects on Cell Functions. Environmental Health Perspectives, 121 (3), 352, 2013.

7. WANG H., WANG S.-F., NING H., JI Y.-L., ZHANG C., ZHANG Y., YU T., MA X.-H., ZHAO X.-F., WANG Q., LIU P., MENG X.-H., XU D.-X. Maternal cypermethrin exposure during lactation impairs testicular development and spermatogenesis in male mouse offspring. Environmental Toxicology, 26 (4), 382, 2011.

8. HOGAN N.S., CURRIE S., LEBLANC S., HEWITT L.M., MACLATCHY D.L. Modulation of steroidogenesis and estrogen signalling in the estuarine killifish (Fundulus heteroclitus) exposed to ethinylestradiol. Aquatic toxicology, 98 (2), 148, 2010.

9. LIU Y.-H., ZHANG S.-H., JI G.-X., WU S.-M., GUO R.-X., CHENG J.,YAN Z.-Y., CHEN J.-Q. Occurrence, distribution and risk assessment of suspected endocrinedisrupting chemicals in surface water and suspended particulate matter of Yangtze River (Nanjing section). Ecotoxicology and Environmental Safety, 135, 90, 2017.

10. OMAR T.F.T., ARIS A.Z., YUSOFF F.M., MUSTAFA S. Occurrence, distribution, and sources of emerging organic contaminants in tropical coastal sediments of anthropogenically impacted Klang River estuary, Malaysia. Marine Pollution Bulletin, 131 (Pt A), 284, 2018.

11. JENG H.A. Exposure to endocrine disrupting chemicals and male reproductive health. Frontiers in Public Health, 2, 55, 2014.

12. PONZO O.J., SILVIA C. Evidence of reproductive disruption associated with neuroendocrine changes induced by UV-B filters, phthalates and nonylphenol during sexual maturation in rats of both gender. Toxicology, 311 (1-2), 41, 2013.

13. MARQUES-PINTO A., CARVALHO D. Human infertility: are endocrine disruptors to blame? Endocrine Connections, 2 (3), R15, 2013.

14. ZHANG L., DONG L., DING S., QIAO P., WANG C., ZHANG M., ZHANG L., DU Q., LI Y., TANG N., CHANG B. Effects of n-butylparaben on steroidogenesis and spermatogenesis through changed $\mathrm{E}_{2}$ levels in male rat offspring. Environmental Toxicology and Pharmacology, 37 (2), 705, 2014

15. LEE K.Y., JUNG H.Y., YOO D.Y., KIM W., KIM J.W., KWON H.J., KIM D.W., YOON Y.S., HWANG I.K., CHOI J.H. Dendropanax morbifera Leveille extract ameliorates D-galactose-induced memory deficits by decreasing inflammatory responses in the hippocampus. Laboratory Animal Research, 33 (4), 283, 2017.

16. JI K., HONG S., KHO Y., CHOI K. Effects of Bisphenol $\mathrm{S}$ Exposure on Endocrine Functions and Reproduction of Zebrafish. Environmental Science \& Technology, 47 (15), 8793,2013

17. SVECHNIKOV K., STUKENBORG J.-B., SAVCHUCK I., SODER O. Similar causes of various reproductive disorders in early life. Asian Journal of Andrology, 16 (1), 50,2014

18. YU M., WANG J., LIU W., QIN J., ZHOU Q., WANG Y., HUANG H., CHEN W., MA C. Effects of tamoxifen on the sex determination gene and the activation of sex reversal in the developing gonad of mice. Toxicology, 321, 89, 2014.

19. JOHNSON K.J., HEGER N.E., BOEKELHEIDE K. Of mice and men (and rats): phthalate-induced fetal testis endocrine disruption is species-dependent. Toxicological Sciences: An Official Journal of the Society of Toxicology, 129 (2), 235, 2012.

20. MARTINEZ-ARGUELLES D.B., CAMPIOLI E., CULTY M., ZIRKIN B.R., PAPADOPOULOS V. Fetal origin of endocrine dysfunction in the adult: the phthalate model. The Journal of Steroid Biochemistry and Molecular Biology, 137, 5, 2013.

21. MOODY S., GOH H., BIELANOWICZ A., RIPPON P., LOVELAND K.L., ITMAN C. Prepubertal Mouse Testis Growth and Maturation and Androgen Production Are Acutely Sensitive to Di-n-butyl Phthalate. Endocrinology, 154 (9), 3460, 2013.

22. CHEN X., AN H., AO L., SUN L., LIU W., ZHOU Z., WANG Y., CAO J. The combined toxicity of dibutyl phthalate and benzo(a)pyrene on the reproductive system of male Sprague Dawley rats in vivo. Journal of Hazardous Materials, 186 (1), 835, 2011.

23. SAEIDNIA S. PHTHALATES. In Encyclopedia of Toxicology, $3^{\text {rd }}$ ed., P. WEXLER, Ed., Academic Press: Oxford, pp. 928, 2014.

24. Darbre P.D. What Are Endocrine Disrupters and Where Are They Found? In Endocrine Disruption and Human Health, P. D. Darbre Ed., Academic Press: Boston, pp. 3, 2015.

25. KHEDKAR G.D., JADHAO B.V., CHAVAN N.V., KHEDKAR C.D. FISH Demersal Species of Tropical Climates. In Encyclopedia of Food Sciences and Nutrition $2^{\text {nd }}$ ed., In B. Caballero (Ed.), Academic Press: Oxford, pp.2438, 2003.

26. EI-GHAMDI F., EL-KASHEIF M., GABER H., IBRAHIM S. Structural Alterations in Gills, Liver and Ovaries of Tilapia Fish (Saratherodon Galilaeus) as a Biomarker for Environmental Pollution in Ismalia Canal. Catrina: The International Journal of Environmental Sciences, 9 (1), 7, 2014.

27. YON N.D., AKBULUT C. Histological changes in zebrafish (Danio rerio) ovaries following administration of bisphenol A. Pakistan Journal of Zoology, 46 (4), 1153, 2014.

28. BRRAICH O.S., JANGU S. Some aspects of reproductive biology on effect of heavy metal pollution on the histopathological structure of gonads in Labeo rohita (Hamilton-Buchanan) from Harike wetland, India. International Journal of Fisheries and Aquaculture, 7 (2), 9, 2015.

29. KUMAR R., JOY K. Melanins as biomarkers of ovarian follicular atresia in the catfish Heteropneustes fossilis: biochemical and histochemical characterization, seasonal variation and hormone effects. Fish physiology and biochemistry, 41 (3), 761, 2015.

30. CHEN Y., WANG S., NAN Z., MA J., ZANG F., LI Y., ZHANG Q. Effect of fluoride and cadmium stress on the uptake and translocation of fluoride and cadmium and other mineral nutrition elements in radish in single element or co-taminated sierozem. Environmental and Experimental Botany, 134, 54, 2017.

31. FERIN M. Gonadotropin Secretion, Effects of Stress on Gonadotropin secretion. In Encyclopedia of Stress $2^{\text {nd }}$ ed.; G. Fink Ed., Academic Press: New York, pp. 228, 2007.

32. HANNON P.R., FLAWS J.A. The Effects of Phthalates on the Ovary. Frontiers in Endocrinology, 6, 2015. 
33. PATEL S., ZHOU C., RATTAN S., FLAWS J.A. Effects of Endocrine-Disrupting Chemicals on the Ovary. Biology of Reproduction, 93 (1), 2015.

34. MIR F., SHAH G.M., JAN U. Studies on Influences of Organophosphate Pesticides on Reproductive Activities of Female Common Carp: Cyprinus carpio communis. Lambert Academic Publishing USA, 2013.

35. PERANANDAM R., PALANISAMY I., LOURDARAJ A.V., NATESAN M., VIMALANANTHAN A.P., THANGAIYAN S., PERUMAL A., MUTHUKALINGAN K. TBT Effects on the Development of Intersex (Ovotestis) in Female Fresh Water Prawn Macrobrachium rosenbergii. BioMed Research International, 2014.

36. RAI S., YADAV K., TRIVEDI S. Ovarian Impairment in Fish, Channa punctata (Bloch) on Exposure to Mercuric Chloride, Caldan $50 \mathrm{SP}$ and their Mixture. Journal of Ecophysiology and Occupational Health, 19 (1\&2), 65, 2018.

37. LUSHCHAK V.I., MATVIISHYN T.M., HUSAK V.V., STOREY J.M., STOREY K.B. Pesticide toxicity: a mechanistic approach. EXCLI Journal, 17, 1101, 2018.

38. SUNANDA M., JAMMU C.S.R., NEELIMA P., RAO K., SIMHACHALAM G. Effects of Chlorpyrifos (an Organophosphate Pesticide) in Fish. International Journal of Pharmaceutical Sciences Review and Research, 39 (1), 299, 2016.

39. CARNEVALI O., SANTANGELI S., FORNER-PIQUER I., BASILI D., MARADONNA F. Endocrine-disrupting chemicals in aquatic environment: what are the risks for fish gametes? Fish Physiology and Biochemistry, 44 (6), 1, 2018.

40. BJÖRVANG R.D., DAMDIMOPOULOU P. Persistent environmental endocrine-disrupting chemicals in ovarian follicular fluid and in vitro fertilization treatment outcome in women. Upsala Journal of Medical Sciences, 125 (2), $85,2020$.

41. MAGAR R.S. Histopathological Impact of Malathion on the Ovary of the Fresh Water fish Channa punctatus. International Research Journal of Environment Sciences, 2(3), 56, 2013

42. MANJUNATHA B., PHILIP G.H. Reproductive toxicity of chlorpyrifos tested in zebrafish (Danio rerio): Histological and hormonal end points. Toxicology and Industrial Health, 32 (10), 1808, 2016.
43. SAKA B., ADEYEMO O., EMIKPE B. Testes Development in Nigerian Clarias gariepinus, Burchell 1822. International Journal of Fisheries and Aquatic Studies, 2, 366, 2015.

44. HENRIQUES M.C., LOUREIRO S., FARDILHA M., HERDEIRO M.T. The Role of Endocrine-Disrupting Chemicals in Male Fertility Decline. In W. WU, F. ZIGLIOLI, \& U. MAESTRONI (Eds.), Male Reproductive Health. IntechOpen, 2020.

45. LORA BENITEZ A.J., MOLINA A., BELLIDO C., BLANCO A., MONTERDE J., MOYANO R. Adverse effects of bisphenol A on the testicular parenchyma of zebrafish revealed using histomorphological methods. Veterinární Medicína, 61, 577, 2016.

46. MASOULEH F.F., AMIRI B.M., MIRVAGHEFI A.R., NEMTOLLAHI M.A. In vitro Effects of Diazinon on Male Reproductive Tissue and Sperm Motility of Caspian Kutum (Rutilus frisii kutum). Research Journal of Environmental Toxicology, 5 (2), 108, 2011.

47. ISLAM F.U., JALALI S., SHAFQAT M.N., SHAH S.T.A. Endosulfan is toxic to the reproductive health of male freshwater fish, Cyprinion watsoni. The Science of Nature, 104, 104, 2017.

48. HASSANZADEH N., MORTAZAVI S. Sublethal Effects of Cadmium Chloride to Testis of Zebrafish (Danio rerio). Journal of Persian Gulf, 7 (23), 51, 2016.

49. LI M., MRUK D., LEE W., CHENG C. Disruption of the blood-testis barrier integrity by bisphenol $\mathrm{A}$ in vitro: Is this a suitable model for studying blood-testis barrier dynamics? The international journal of biochemistry \& cell biology, 41 (11), 2302, 2009.

50. HAYATI A., PRATIWI H., KHOIRIYAH I., WINARNI D., SUGIHARTO. Histopathological assessment of cadmium effect on testicles and kidney of Oreochromis niloticus in different salinity. AIP Conference Proceedings, 1854, 020014, 2017.

51. SHEN L.-J., TANG X.-L., LONG C.-L., CAO X.-N., WEI Y., WANG Y.-C., SUN M., ZHOU Y., LIU Y., LIU B., HUANG F.-Y., WEI G.-H. Effect of Di-(2-ethylhexyl) phthalate exposure on blood-testis barrier integrity in rats. Journal of Southern Medical University, 37 (9), 1178, 2017. 